\title{
Factors Influencing Millennials' Purchase Intention towards Fast Fashion Products: A Case Study in Vietnam
}

\author{
Han Gia Vuong and Minh Tan Nguyen
}

\begin{abstract}
This paper is aimed to identify factors influencing purchase intention of Millennials towards fast fashion products in Vietnam. The study is conducted by quantitative approach with data collection from 430 respondents in Hochiminh City and Binh Duong Province, Vietnam in December 2017. The results were investigated by descriptive analysis, reliability analysis, exploratory factor analysis, correlation analysis, and regression analysis. The research discloses a significant finding: all seven factors including Perceived Price, Perceived Quality, Brand Consciousness, Fashion Consciousness, Hedonic Shopping Value, Store Environment, and Sales Promotion have positive influence on millennials' purchase intention towards fast fashion products. The research contributes to the field of fast fashion industry by highlighting the remarkableness of these factors which linked to some particular characteristics of Millennials generation.
\end{abstract}

Index Terms-Fast fashion, Millennials, purchase intention.

\section{INTRODUCTION}

The fashion industry has significantly evolved and attracted many customers in different levels. The industry can no longer base on price only to compete, it forces retailers to desire low cost, and flexibility in design, quality, delivery, and speed to the market to recruit and retain potential customers [1]. Therefore, fast fashion is developing continuously to meet these demands. The economy of Vietnam has experienced a rapid growth in many recent years and Vietnam is one of the fastest developing countries with a huge population. According to World Bank, average annual income has risen by $4.8 \%$ and reached $\$ 2,200$ in 2016 . The number of middle and high-income consumers is steadily increasing, and will double to 33 million people by 2020 , which accounts for about a third of the population, reported by the Nikkei Asian Review [2]. Additionally, these customers are well conscious of the latest fashion trend and have a strong aspiration to purchase fast fashion brands, which refer those that mass-produce and sell affordable clothing by rapidly adapting the newest trends. As a result, many international fashion brands realized these potential advantages and had plans to roll out in Vietnamese market, e.g.: Mango in 2004, Topshop-Topman in 2013, Zara in 2016, and recently, H\&M in 2017. On September $9^{\text {th }}, 2017$, there was a very long line of more than 4,000 people (almost Millennials shoppers) who queued in front of H\&M's very first store at Vincom Dong Khoi in Ho Chi Minh City,

Manuscript received January 12, 2018; revised May 1, 2018.

Han G. Vuong and Minh T. Nguyen are with the School of Business of International University, Vietnam National University in Ho Chi Minh City, Vietnam (e-mail: vuonghan96@gmail.com,ntminh@hcmiu.edu.v).
Vietnam on the grand opening day, gaining a lot of attention [3]. It can be seen that fast fashion is now stirring up a fever in Vietnam and it is worth understanding factors influencing on purchase intention of millennials in Vietnam towards fast fashion products by applying the quantitative research method in this paper. The tested factors are Perceived Price, Perceived Quality, Brand Consciousness, Fashion Consciousness, Hedonic Shopping Value, Store Environment, and Sales Promotion and this study will answer these questions:

1) Which factors influence millennials' purchase intention towards fast fashion products?

2) To what extent does each factor influence purchase intention?

3) What are suggestions for businesses in fast fashion industry to develop suitable manufacturing and marketing strategies?

This study will help retailers understand millennials' perceptions and emotions about their products, how they perceive and value brands. Then based on that, brand managers figure out strategies to improve their image together with experience their brands provide for millennials, and then develop the strength of brands in this young generation's minds.

\section{LITERATURE REVIEW}

\section{A. Fast Fashion}

Fast fashion can be defined from the perspective of business concept as a strategy which targets to decrease the phases included in buying cycle and lead times. The prior objective of fast fashion is introducing new collections of outfits into stores as soon as possible so as to meet shoppers' demand at its highest point [4].

\section{B. Millennials}

Millennials - a term coined by Howe and Strauss (2000) is a group of consumers among three major groups including Baby Boomers and Generation X [5]. In this study, Millennials or Generation $\mathrm{Y}$ is a collective term used to refer to those born between 1980 and 2000 [6] - [8]. This generation is a group of huge potential customers for fast fashion industry because Generation $\mathrm{Y}$ are quite fashion conscious are willing to consume two-thirds of their income on fashion products [9], [10] less price conscious, are quite keen on hedonism, refer to word-of-mouth reviews, have a strong passion to try novelties, purchase more costly items and pay more than other age cohorts [11]. 


\section{Purchase Intention (PI)}

According to Warshaw and Davis (1985), planning in advance to purchase certain goods or services in the future is purchase intention of which the probability to be executed or not depends on individual's ability to perform [12]. In addition, purchase intention can be understood as intention to buy a specific product they are keen on after certain evaluations. Specifically, customers tend to purchase a product that satisfy their needs and wants.

\section{Relationship between Independent Variables and Purchase Intention}

\section{1) Perceived price (PP)}

Perceived price is considered as the subjective clarification on the monetary value of the product, to examine whether it is as cheap or expensive. Price is considered as a reflection of costs and in marketing, price plays a pivotal role to gain attentions from customers and it is also used as a tool to convey some messages to consumers about the product and brand perception. Moreover, it can influence consumers' decision-making process [13]. In more developed countries, Zara, H\&M, Mango or Topshop always take pride of their offered reasonable price with pretty good quality. Additionally, Millennials are less price conscious, and have a tendency towards spending more money in the store than other age group [11]. Roberts and Manolis (2000) found that younger generations are more likely to associate higher prices with improved quality and worth [14].

\section{2) Perceived quality $(P Q)$}

Perceived quality is defined as the assessment of consumers about a product's overall distinction or superiority [15]. According to Snoj (2004), consumers often compare the certain performance of a brand in general and a product in specific with their expectations, as a result, it creates perception of quality [16]. Perceived quality creates the value of worthwhile purchase and stimulate spiritually to repurchase the next times [17]. If consumers realize the products' real value and perceive the brand offering the right characters, quality and performance benefits which are similar with advertisements, they will intend to purchase this specific brand. The products in good quality will be highly estimated and linked with the reputation of a particular brand, so it is a great advantage in competing with other competitors in the market [18].

\section{3) Brand consciousness (BC)}

Brand consciousness is the notion presenting that brands play a pivotal role in the psychological process that precedes the buying act [19]. These consumers also like purchasing expensive and famous brands of clothing. There are some studies defined the positive relationship between brand consciousness and purchase intention, for example, towards luxury products among millennials customers of Kim and Lee (2011) [20]. According to Kwan, Yeung and Au (2004), in comparison with other people, consumers who are brand conscious have a tendency to purchase well-known international brands with costly and stylish apparels [21]. Among fashion brands, Zara and H\&M are the two most valuable fast fashion brands that have developed remarkably outside its home countries. Furthermore, Generation Y are found to be not only brand conscious but also innovative [22].

\section{4) Fashion consciousness (FC)}

Consumers who are fashion conscious adapt well to the latest trends in apparel market which can be seen as strategic consumers. The more they are interested in fashion, the more they will search for fashion-related information. In comparison with other people, fashion conscious customers spend more time to shop and find the fresh items [23]. In addition, fast fashion brands introduce the new collections within a minimum of three to five weeks by adding five mid-seasons to a fashion calendar. According to Colucci and Scarpi (2013), people in Generation Y are more willing to try novelties, materialistic and receptive to new products than Generation X [11]. They want to be visibly fashionable and use their outlook to define themselves.

\section{5) Hedonic shopping value (HSV)}

Shopping is sometimes considered as an entertaining activity and allows people to be in a merry mood. This value refers to hedonic shopping one [24]. It is fairly interesting that hedonic value permits consumers to experience the advantage of a product without buying it. Overall, consumers who are hedonistic do not feel that shopping is a sheer waste of time. In addition, they acquire enthusiasm and eagerness through the task of shopping, often by purchasing something fresh and different. Generation Y are found to be more likely to hedonism and less utilitarian, and enjoy the fun of going out for buying new items [11].

\section{6) Store environment (SE)}

There are three components included in store environment: social (e.g., well-dressed manner, friendliness, and helpful of employees), design (e.g., organized merchandised, pleasing color scheme, and attractive facilities), and ambient (e.g., light, scent, and music in store) [25]. It is quite interesting that store environment is one of the most important factors that directly encourages customers to purchase and, concurrently convinces them to repurchase in the future indirectly [26]. The better the physical environment at stores is, the more customers gain excitement, the longer they desire to stay.

\section{7) Sales promotion $(S P)$}

Sales promotion is a tool to fulfill various marketing objectives, such as encouraging sale force interest, boosting sales for a mature brand, facilitating the introduction of new products, raising space for on-shelf and off-shelf merchandises, stimulating patronage purchases, and supporting advertising. There are two categories in sales promotions: monetary or price promotions and non-monetary promotions. For details, monetary promotions include discounts, coupons, or rebates. Non-monetary promotions consist of free samples, gifts, contests, distribution of promotional prizes or membership programs. Over the past decades, sales promotions have influence on perception and attitude of shoppers, both in monetary and non-monetary, and also customers' purchase intention [27]. Furthermore, consumers have a tendency to take sales promotion into 
consideration before making any purchase [28]. Regarding to above factors, the research proposes the following hypotheses:

$\mathrm{H}_{1}$ : Perceived Price has a positive impact on purchase intention of Millennials towards fast fashion products.

$\mathrm{H}_{2}$ : Perceived Quality has a positive impact on purchase intention of Millennials towards fast fashion products.

$\mathrm{H}_{3}$ : Brand Consciousness has a positive impact on purchase intention of Millennials towards fast fashion products.

$\mathrm{H}_{4}$ : Fashion Consciousness has a positive impact on purchase intention of Millennials towards fast fashion products.

$\mathrm{H}_{5}$ : Hedonic Shopping Value has a positive impact on purchase intention of Millennials towards fast fashion products.

$\mathrm{H}_{6}$ : Store Environment has a positive impact on purchase intention of Millennials towards fast fashion products.

$\mathrm{H}_{7}$ : Sales Promotion has a positive impact on purchase intention of Millennials towards fast fashion products.

\section{Methodology}

\section{A. Questionnaire Design and Data Collection}

To reach the research objectives, the quantitative research method was applied. 445 questionnaires were distributed to people who was born from 1980 to 2000 living in Ho Chi Minh City and Binh Duong Province. They have heard, or known, or experienced on at least one fast fashion brand in order to collect their opinions. At the same time, the survey also distributed to the target population through online Google Form. The questionnaire is originally written in English and then is translated into Vietnamese to ensure that respondents understand and answer easily. To measure the attitudes of respondents in this study, the questionnaire will be designed in the form of Likert 5-point-scale, in which 1 (strongly disagree), 2 (disagree), 3 (neither agree nor disagree), 4 (agree) and 5 (strongly agree). There were 430 valid responses. The data analysis process includes (1) descriptive analysis, (2) reliability analysis, (3) exploratory factor analysis, (4) correlation analysis, and (5) regression analysis.

\section{B. Factor Analysis and Reliability}

There were 40 observed items used in reliability analysis, in which, there were some items of each variable have been removed due to its Corrected Item-Total Correlation $<0.3$ or Cronbach's Alpha if item deleted is higher than Cronbach's Alpha of the scale. After conducting reliability test, Exploratory Factor Analysis (EFA) is used to assess and refine measurement scale. Moreover, EFA also deletes invalid items and rearranges valid items into appropriate groups.

TABLE I: SUMMARY OF DEPENDENT VARIABLE WITH RELIABILITY COEFFICIENT

\begin{tabular}{ccc}
\hline Variables & Cronbach's Alpha & Number of items \\
\hline Purchase Intention & 0.850 & $4 *$ \\
\hline
\end{tabular}

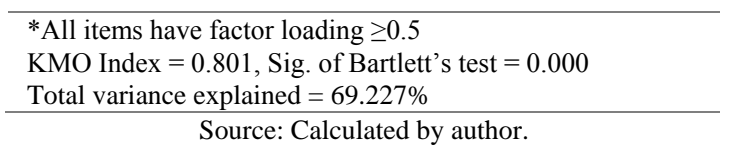

Cronbach's Alpha equals $0.850>0.6$ and there is no corrected item-total correlation that is smaller than 0.3 . Thus, the observed items of Purchase Intention are reliable and well designed. The KMO Index is $0.801>0.5$ and the significance level of Bartlett's test $=0.000<0.05$. Thus, EFA is appropriate to be conducted. The Eigenvalue of the extract component is $2.769>1$; and the total variance explained equals to $69.227 \%$, which satisfy the requirement of being greater than $50 \%$.

TABLE II: SUMMARY OF INDEPENDENT VARIABLE WITH RELIABILITY COEFFICIENT

\begin{tabular}{lcc}
\multicolumn{1}{c}{ Variables } & Cronbach's Alpha & Number of items \\
\hline Perceived Price & 0.727 & $3^{*}$ \\
\hline Perceived Quality & 0.819 & $3^{*}$ \\
\hline Brand Consciousness & 0.766 & $6^{*}$ \\
\hline Fashion Consciousness & 0.814 & $5^{*}$ \\
\hline Hedonic Shopping Value & 0.792 & $3^{*}$ \\
\hline $\begin{array}{l}\text { Store Environment } \\
\text { Sales Promotion }\end{array}$ & 0.842 & $5 *$ \\
\hline $\begin{array}{l}\text { KAll items have loading factor } \geq 0.5 \\
\text { Total variance explained }=62.346 \%\end{array}$ & \\
\hline$\quad$ Source: Calculated by auzthor.
\end{tabular}

Cronbach's Alpha ranges from 0.727 to 0.842 which suggests good reliability of measurement scale. However, because corrected item-total correlation is smaller than $0.3,2$ items in Perceived Price are deleted. Moreover, 1 item in Perceived Quality and 1item in Hedonic Shopping Value are eliminated since Cronbach's Alpha if item deleted is higher than Cronbach's Alpha of the scale. The KMO Index is $0.920>0.5$ and the significance level of Bartlett's test = $0.000<0.05$. Thus, the measured data is suitable for EFA. There are 7 extracted components which correspond to the concepts of Fashion Consciousness, Sales Promotion, Store Environment, Perceived Quality, Hedonic Shopping Value, Brand Consciousness, and Perceived Price. The total variance explained by extracted items is $62.346 \%>50 \%$ which means that extracted components can explain $62 / 346 \%$ of the variation.

\section{RESEARCH FINDINGS}

\section{A. Sample Description}

There were 430 respondents participating in this survey. The percentage of female and male respondents are $59 \%$ and $41 \%$, respectively. Regarding to the education background, the highest proportion belongs to Associate Degree/Bachelor's Degree with 68\%. This is followed by respondents who have High School Diploma or under 
account for $16 \%$. The figures for Master's Degree or above and Vocational Degree are $9 \%$ and $7 \%$, respectively. About personal monthly income or being supported by family, most of respondents have salary under US\$440 per month (76\%). Next, people who have salary from US\$440 to US\$660 per month occupied $13 \%$. The two smallest group are respondents having salary from US\$660 to US\$1,100/month and above US\$1,100/month which accounted for $7 \%$ and $4 \%$, respectively.

\begin{tabular}{llcc}
\multicolumn{4}{c}{ TABLE III: SUMMARY PROFILE OF RESPONDENTS } \\
\hline \multicolumn{1}{c}{ Items } & \multicolumn{1}{c}{ Labels } & Frequency & $\begin{array}{c}\text { Percentage } \\
(\%)\end{array}$ \\
& & & 40.9 \\
\hline Gender & Male & 176 & 59.1 \\
& Female & 254 & 100 \\
& Total & 430 & 15.8 \\
Level of & High School or under & 68 & 7.0 \\
education & Vocational Graduate & 30 & 67.9 \\
& Associate / Bachelor's & 292 & \\
& Degree & & 9.3 \\
& Master's degree or above & 40 & 100 \\
& Total & 430 & 76.5 \\
Monthly & $<$ US $\$ 440$ & 329 & 13.0 \\
Income (or & US $\$ 440-$ US\$660 & 56 & 6.7 \\
supported & US $\$ 660-$ US\$1,100 & 29 & 3.7 \\
by family) & $>$ US $\$ 1,100$ & 16 & 100 \\
& Total & 430 & \\
\hline
\end{tabular}

\section{B. Correlation Analysis}

Correlation analysis is a statistical approach used to investigate the strength of a relationship between two variables which can be either positive or negative. Table IV illustrates that all seven independent variables have a positive relationship with Purchase Intention in different levels. In these relationship, there are two most significant correlations between FC and PI ( $r=0.375, \mathrm{p}=0.000)$ and between SP and PI $(r=0.319, p=0.000)$. There are moderate relationships between SE and PI ( $\mathrm{r}=0.290, \mathrm{p}=0.000)$; $\mathrm{PP}$ and PI $(\mathrm{r}=0.238$, $\mathrm{p}=0.000)$; PQ and PI $(\mathrm{r}=0.237, \mathrm{p}=0.000)$. On the other hand, the Pearson correlation shows that there are two low correlations between HSV and PI $(r=0.196, p=0.000)$; BC and PI $(r=0.132, p=0.000)$.

TABLE IV: PEARSON CORRELATION BETWEEN INDEPENDENT VARIABLES

\begin{tabular}{l|cccccccc}
\multicolumn{7}{c}{ AND PURCHASE INTENTION } \\
\hline & 1 & 2 & 3 & 4 & 5 & 6 & 7 & 8 \\
\hline 1.PI & 1 & & & & & & & \\
2.FC & $0.375^{* *}$ & 1 & & & & & & \\
3.SP & $0.319^{* *}$ & & 1 & & & & & \\
4.SE & $0.290^{* *}$ & & & 1 & & & & \\
5.PP & $0.238^{* *}$ & & & & 1 & & & \\
6.PQ & $0.237^{* *}$ & & & & & 1 & & \\
7.HSV & $0.196^{* *}$ & & & & & & 1 & 1 \\
$8 . \mathrm{BC}$ & $0.132^{* *}$ & & & & & & & 1 \\
\hline
\end{tabular}

** Correlation is significant at the 0.01 level (2-tailes).

Source: Calculated by author.

\section{Regression Analysis}

As shown on the table $\mathrm{V}$, the value of standardized coefficients $\beta$ are all greater than 0 , and the significance values are all less than 0.5 . These numbers indicate that every 1 standard deviation increases in each of FC, SP, SE, PP, PQ, $\mathrm{HSV}$, and BC will increase PI by $0.375,0.319,0.290,0.238$,
$0.237,0.196,0.132$. The degree of impact of these independent variables on Purchase Intention could be depicted through the following multiple regression equation:

$$
\mathrm{PI}=0.375 * \mathrm{FC}+0.319 * \mathrm{SP}+0.290 * \mathrm{SE}+0.238 * \mathrm{PP}+
$$$$
0.237 * \mathrm{PQ}+0.196 * \mathrm{HSV}+0.132 * \mathrm{BC}(1)
$$

Equation (1) shows that the most influential factor on Purchase Intention of Millennials towards fast fashion products is Fashion Consciousness with a standardized $\beta$ coefficient of 0.375 , followed by Sales Promotion, and Store Environment with a standardized coefficient of 0.319 and 0.290 , respectively.

TABLE V: COEFFICIENTS BETWEEN INDEPENT VARIABLES AND PURCHASE

\begin{tabular}{cccc}
\multicolumn{4}{c}{ INTENTION } \\
\hline Variables & $\begin{array}{c}\text { UNSTANDARDIZED } \\
\text { COEFFICIENT }\end{array}$ & $\begin{array}{c}\text { Standardized } \\
\text { Coefficient }\end{array}$ & Sig. \\
\hline Cons. & 9.516 E-017 & \\
FC & 0.375 & 0.375 & 0.000 \\
SP & 0.319 & 0.319 & 0.000 \\
SE & 0.290 & 0.290 & 0.000 \\
PQ & 0.237 & 0.237 & 0.000 \\
HSV & 0.196 & 0.196 & 0.000 \\
BC & 0.132 & 0.132 & 0.000 \\
PP & 0.238 & 0.238 & 0.000 \\
\multicolumn{4}{c}{ DEPENDENT VARIABLE: PI } \\
& ANOVA: F=59.117; SIG. $=0.000$ & \\
& MODEL SUMMARY: ADJUSTED R2 20.487 & \\
\hline
\end{tabular}

The Adjusted R Square is checked with the value 0.487 or $48.7 \%$. This result indicates that the formulated regression equation is expected to explain $48.7 \%$ the variation in Purchase Intention of Millennials towards fast fashion products, while the remaining $51.3 \%$ of the variation in the Purchase Intention can be clarified by other factors which were not included in this research.

\section{DISCUSSION AND RECOMMENDATION}

All seven factors (Perceived Price, Perceived Quality, Brand Consciousness, Fashion Consciousness, Hedonic Shopping Value, Store Environment, and Sales Promotion) influence positively Purchase Intention of Millennials towards fast fashion products. Among them, Fashion Consciousness has the most significant influence on the purchase intention. This result confirms the finding in the study of Anić and Mihić (2015) [29]. Moreover, Millennials are considered to be potential consumers of fast fashion industry. This finding proves that they are big fans of new styles and the latest trend. These shoppers pay more on new and fashionable apparel to be visibly fashionable. It can be demonstrated that compared to Generation $\mathrm{X}$, generation $\mathrm{Y}$ has strong desire to try novelties and define themselves through their outlook.

Secondly, from the result of this research, sales promotion is the second most significant factor that has a positive impact on purchase intention. This supports the result of Alvarez and Casielles (2005) [30]. According to Yusuf (2010), purchasing merchandise in sales promotion period creates the feeling of gaining a good buy and save more money [31]. This finding shows that Millennials are also quite keen on sales promotion.

Thirdly, store environment is the third factor that 
significantly has a positively effect on purchase intention of millennials towards fast fashion products. This result is consistent with the research of Shoemaker S. (1998) [32]. It indicates that store environment attracts consumers strongly which affects the way consumers perceive the product's quality. Moreover, Millennials usually consider shopping as an adventure to explore something new, so appealing store environment gives consumers curiosity to explore the beauty inside and creates intention to come in and purchase apparel products.

Finally, based on the research findings, we give some recommendations that fast fashion retailers may find it useful and pay more attention to attract their potential consumers.

Attractive and fashionable styling plays pivotal role in millennials' mind. It is essential to update the product ranges more frequently with the new items following the latest trend every few weeks. Additionally, retailers should concentrate on distinct designs, materials, colors, sizes and purposes in their collections. Fashion conscious consumers always look for the new fashion trend through observing the catalogues, people outside, in store public showings, on social media, or reading fashion magazines, or even word-of-mouth from their friends and colleagues. Therefore, the introduction of the hottest trend and the newest collection should be cover all mentioned above channels in order to maximize the effectiveness.

Sales promotion is considered as one of the most powerful tool to attract consumers' purchase intention. Since consumers think that discount price in sales promotion programs is lower than normal price, they feel that they spend the same amount of money but be able to purchase more items than usual. The higher the favorable attitude towards promotional tools are, the higher the likelihood consumers come and buy fast fashion products will be. Therefore, it is suggested that fast fashion retailers should offer sales promotion in special occasion (for instance, Grand Opening Day, Christmas, New Year's Eve, etc....) to gain attention from consumers and impulse buying behaviors. Moreover, sales promotion can be implemented under various forms. For example, sale discounts or free samples on grand opening day; voucher or coupon after transactions in order to encourage consumers to repurchase the next time. By offering the attractive promotional strategies, it can help retailers to maximize profit and broaden their image in consumers' mind.

Appealing store environment also increases intention to purchase fast fashion products in Millennials consumers' mind. Fast fashion retailers should take their store's light, scent, cleanness as well as interior decoration into consideration to increase millennials' curiosity. Lighting creates an atmosphere which visitors find so appealing and it also beautifies the visibility of clothing. Additionally, in-store pleasing scent is a factor that also gives first impression to consumers. The store's merchandise should be arranged conveniently and easily seen in order for Millennials consumers to explore and try out. Furthermore, managers ought to pay attention to the store environmental cleanliness because it represents the brand's first image to buyers and motivate them to pay a visit again. It is also suggested to play music to let consumers feel comfortable atmosphere in fast fashion stores.

\section{CONCLUSION}

The research accomplished the objective of identifying factors influencing purchase intention of Millennials towards fast fashion products in Vietnam. By applying quantitative research method together with using reliability analysis, exploratory factor analysis, correlation analysis, and regression analysis, the study confirms the significance of fashion consciousness, sales promotion, and store environment in the correlation with purchase intention. The sample of this study is 430 , which mainly concentrated in Ho Chi Minh City and Binh Duong province, considered as good according to Comfrey and Lee (1992) [33]. However, due to time limit and undesirable geographical conditions, this research is still limited and does not represent the whole Millennials population in Vietnam. It is recommended that the future researches should base their studies upon the results obtained from this research and increase the sample to be bigger in order to get the better and more accurate result. Finally, among seven factors influencing purchase intention of Millennials towards fast fashion products, there are five factors representing the special characteristics of Millennials generation (Fashion consciousness, Perceived price, Perceived quality, Hedonic shopping value, and Brand consciousness). When conducting future research, it is recommended to find more determinants that linked with Millennials' characteristic so as to be more valuable. Although there are still some limitations, this study incorporates insights from Millennials consumers' minds and explores many useful factors that fast fashion retailers in Vietnam or have a plan to enter Vietnam market should take into consideration.

\section{REFERENCES}

[1] S. A. Doyle, C. M. Moore, and L. Morgan, "Supplier management in fast moving fashion retailing," Journal of Fashion Marketing and Management: An International Journal, vol. 10, no. 3, pp. 272-281, 2006.

[2] R. Jennings. (October, 2016). Growing affluence in Vietnam lures foreign brands. Nikkei Asian Review. [Online]. Available: https://asia.nikkei.com/Business/Trends/Growing-affluence-in-Vietna m-lures-foreign-brands

[3] F. Carrasco. (September 2017). How fast fashion is emerging at pace in Vietnam. VNExpress News. [Online]. Available: https://e.vnexpress.net/news/news/perspectives/how-fast-fashion-is-e merging-at-pace-in-vietnam-3643814.html

[4] L. Barnes and G. Lea-Greenwood, "Fast fashioning the supply chain: shaping the research agenda," Journal of Fashion Marketing and Management: An International Journal, vol. 10, no. 3, pp. 259-271, 2006.

[5] N. Howe and W. Strauss, Millennials Rising: The Next Great Generation, Vintage, 2009

[6] J. W. Gibson, R. A. Greenwood, and E. F. Murphy Jr, "Generational differences in the workplace: Personal values, behaviors, and popular beliefs," Journal of Diversity Management, vol. 4, no. 3, 2009.

[7] R. Alsop, "The trophy kids grow up: How the millennial generation is shaking up the workplace," John Wiley \& Sons, 2008.

[8] S. P. Eisner, "Managing generation," Y. SAM Advanced Management Journal, vol. 70, no.4, pp. 4-15, 2005.

[9] C. Bakewell and V. W. Mitchell, "Generation Y female consumer decision-making styles," International Journal of Retail \& Distribution Management, vol. 31, no. 2, pp. 95-106, 2003.

[10] J. Kim, and J. Park, "A consumer shopping channel extension model attitude shift toward the online store," Journal of Fashion Marketing 
and Management: An International Journal, vol. 9, no. 1, pp. 106-121, 2005.

[11] M. Colucci and D. Scarpi, "Generation Y: Evidences from the fast-fashion market and implications for targetin," Journal of business theory and practice, vol. 1, no. 1, 2013.

[12] P. R. Warshaw and F. D. Davis, "The accuracy of behavioral intention versus behavioral expectation for predicting behavioral goals," The Journal of psychology, vol. 119, no. 6, pp. 599-602, 1985.

[13] T. S. Erdil, "Effects of customer brand perceptions on store image and purchase intention: An application in apparel clothing," Procedia-Social and Behavioral Sciences, vol. 207, pp. 196-205, 2015.

[14] J. A. Roberts and C. Manolis, "Baby boomers and busters: an exploratory investigation of attitudes toward marketing, advertising and consumerism," Journal of Consumer Marketing, vol. 17, no. 6, pp. 481-497, 2000

[15] V. A. Zeithaml, "Consumer perceptions of price, quality, and value: a means-end model and synthesis of evidence," The Journal of marketing, pp. 2-22, 1988.

[16] B. Snoj, A. P. Korda, and D. Mumel, "The relationships among perceived quality, perceived risk and perceived product value," Journal of Product and Brand Management, vol. 13, no. 3, pp. 156-167, 2004.

[17] B. J. Babin, W. R. Darden, and M. Griffin, "Work and/or fun: measuring hedonic and utilitarian shopping value," Journal of consumer research, vol. 20, no. 4, pp. 644-656, 1994.

[18] Yoo, "The determinants of perceived service quality and its relationship with satisfaction," Journal of services marketing, vol. 14, no. 3, pp. 217-231, 2000.

[19] M. J. Lachance, P. Beaudoin, and J. Robitaille, “Adolescents' brand sensitivity in apparel: Influence of three socialization agents. International," Journal of Consumer Studies, vol. 27, no. 1, pp.47-57, 2003.

[20] J. Kim and H. H. Lee, "The impact of shopping orientations on US consumer's retail channel choice behavior toward luxury goods purchases," Journal of Global Fashion Marketing, vol. 2, no. 4, pp. 188-199, 2011

[21] C. Y. Kwan, K. W. Yeung, and K. F. Au, "Decision-making behaviour towards casual wear buying: A study of young consumers in Mainland China," Journal of Management \& World Business Research, vol. 1, no. 1, pp. 1-10, 2004.

[22] K. H. Hanzaee and S. Aghasibeig, "Generation Y female and male decision-making styles in Iran: Are they different?" The International Review of Retail, Distribution and Consumer Research, vol. 18, no. 5, pp. 521-537, 2008.

[23] R. Iyer and J. K. Eastman, "The fashion conscious mall shopper: An exploratory study," Marketing Management Journal, vol. 20, no. 2, pp. 42-53, 2010.

[24] D. N. Bellenger, E. Steinberg, and W. W. Stanton, "Congruence of store image and self image-as it relates to store loyalty," Journal of retailing, vol. 52, no. 1, pp. 17-32, 1976.
[25] J. Baker, A. Parasuraman, D. Grewal, and G. B. Voss, "The influence of multiple store environment cues on perceived merchandise value and patronage intentions," Journal of marketing, vol. 66, no. 2, pp. 120-141, 2002.

[26] R. Hussain and M. Ali, "Effect of store atmosphere on consumer purchase intention," International Journal of Marketing Studies, vol. 7, no. $2,2015$.

[27] R. C. Blattberg and S. A. Neslin, "Sales promotion: Concepts, methods, and strategies," Prentice Hall, 1990.

[28] L. Percy, J. R. Rossiter, and R. Elliott, "Promotion tactics, strategic advertising management," Oxford University Press, Oxford, 2001.

[29] I. D. Anić and M. Mihić, "Demographic profile and purchasing outcomes of fashion conscious consumers in Croatia," Ekonomski pregled, vol. 66, no. 2, pp. 103-118, 2015.

[30] B. A. Alvarez and R. V. Casielles, "Consumer evaluations of sales promotion: the effect on brand choice," European Journal of Marketing, vol. 39, no. 1, pp. 54-70, 2005.

[31] J. Yusuf, "Ethical implications of sales promotion in Ghana: Islamic perspective," Journal of Islamic Marketing, vol. 1, no. 3, pp. 220-230 2010.

[32] S. Shoemaker, "Loyalty: A strategic commitment," The Cornell Hotel and Restaurant Administration Quarterly, vol. 39, no. 1, pp. 12-25, 1998.

[33] A. L. Comfrey and H. B. Lee, "Hillsdale, NJ: Lawrence Erlbaum Associates," A First Course in Factor Analysis.

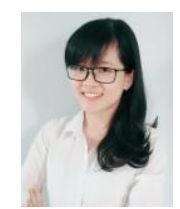

Han Gia Vuong is currently a senior student of School of Business at International University, Vietnam National University in Ho Chi Minh City (VNU - HCMC). Her research interests include Marketing and Human Resource Management.

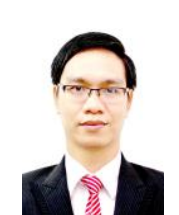

Minh Tan Nguyen is currently a full-time lecturer at International University, Vietnam National University in Ho Chi Minh City. He earned his MBA degree from University of Houston - Clear Lake, Texas, United States in 2009 and pursuing his career in Human Resources Management since then. His research interests include Human Resources Management, Organizational Behavior and Business 